\title{
Analysis of Risk Management and Profits for Salin Minapadi Farmers Windu Shrimp
} in Rammang-Rammang

\author{
Dewi Permatasari ${ }^{1}$, Hamzah Tahang ${ }^{2}$, Sahabuddin ${ }^{3}$ \\ ${ }^{1}$ Students of the Graduate School of Hasanuddin University, Indonesia \\ ${ }^{2}$ Lecturer Hasanuddin University, Indonesia \\ ${ }^{3}$ Researcher of the Research Institute for Brackish Water Aquaculture and Fishery Extension, \\ Indonesia
}

Received: January 2, 2022

Revised: January 22, 2022

Accepted: February 4, 2022

\begin{abstract}
Rammang-rammang District, Maros Regency, is one of the agricultural areas experiencing seawater intrusion, so many farmers leave their land idle. In the era of increasingly modern technology, now there is a combination of technological advances in the fields of agriculture and fisheries which is starting to develop, namely salin minapadi cultivation. Salin minapadi is one of the cultivation techniques that combines the cultivation of tiger prawns and rice that can live in brackish water but it is not easy because it is necessary to know whether salin minapadi is profitable and there is a possibility of developing salin minapadi faced with risks and the question of whether it is profitable. To reduce and overcome, the profit analysis method and the House of Risk (HOR) method are used. The profit analysis method is to find out how much profit the salin minapadi farmers make while the House of Risk (HOR) method is to minimize the risks that can cause problems in salin minapadi cultivation. The yield from the profit of salin minapadi is IDR 37,926,167 / Ha / MT. Identification of risk events and risk agents was carried out through interviews and observations in salin minapadi in RammangRammang District. The results of this HOR analysis show that there are 10 risk causes and 6 recommended risk management methods for risk management for salin minapadi.
\end{abstract}

Keywords: Salin Minapadi, Profit, House of Risk

\section{Introduction}

One of the national development objectives is to increase the income of farmers. The growth of agriculture is heavily influenced by the availability of human resources in the field. Human resources with high levels of enthusiasm, inventiveness, and the ability to produce innovation will undoubtedly contribute to improved agricultural growth. Consequently, it is vital to work towards farmer empowerment in order to increase the capacity of human resources (S. Lestari \& Bambang, 2017).

In the era of increasingly modern agricultural technology, now there are technological advances in the combined fields of agriculture and fisheries which are starting to develop, namely Minapadi cultivation. Minapadi is a way of raising fish between rice plants (Fatimah et al., 2020). Minapadi saline is a cultivation technique that combines the cultivation of tiger prawns that can live in brackish water with rice that can live in brackish water. Developing saline minapadi cultivation which will have the potential and have a comparative advantage but is not easy because there will be a possibility that the development of saline minapadi is faced with risks and uncertainties (uncertainty) (Prasetyo et al., 2018). 
Minapadi saline is an innovation and is a technological solution for areas where seawater intrusion occurs, causing the area to become stagnant and cannot be used for agricultural land. The success of this technology depends on the maintenance and management of an environment that is suitable for the life of rice and tiger prawns because rice and tiger prawns have different salinity and handling. Farmers need a good strategy in managing Minapadi cultivation (Badriyah et al., 2020).

Currently, farmers are still lacking knowledge about understanding the saline mining system in Indonesia by utilizing idle land. So farmers need to be given directions and strategies in the management of saline Minapadi cultivation, risk management of saline Minapadi cultivation and the many benefits of farmers when developing saline Minapadi cultivation.

\section{Methods}

Data processing was carried out with the help of excel and to answer the identification of the problem of comparison of farmer profits, namely by calculating the income level of rice farmers in the Minapadi and non-Minapadi systems, it was analyzed using income calculations (Sauqie et al., 2017).

Total cost is the sum total of fixed costs and variable costs incurred to produce the product. This statement can be written as follows:

$\mathrm{TC}=\mathrm{FC}+\mathrm{VC}$

$\mathrm{TC}=$ total cost

$\mathrm{FC}=$ fixed cost

$\mathrm{VC}=$ variable cost

Business acceptance is the multiplication between the production produced and the selling price. This statement can be written as follows:

$$
\mathrm{TR}=\mathrm{Y} . \mathrm{Py}
$$

$\mathrm{TR}=$ total receipts

$\mathrm{Y}=$ production produced

Py $=$ selling price of product $y$

Analysis of the profits of the farm itself is very useful for farmers to measure the success rate of their farmers. This statement can be written as follows:

$$
\Pi=\mathrm{TR}-\mathrm{TC}
$$

$\Pi=$ profit

$\mathrm{TR}=$ total receipts

$\mathrm{TC}=$ total cost

\section{Identify risk factors}

To identify the various risk factors of copy minapadi farming using House Of Risk (HOR) analysis. The HOR approach aims to identify risks (Hadi et al., 2020). Regarding the sources of production risk, market risk, institutional risk, human risk, and financial risk they face in oil palm cultivation (Winarso \& Jufriyanto, 2020). 


\section{Risk Management Analysis}

Risk management in the face of business risk minapadi is known by using House of Risk (HOR) analysis. The HOR approach aims to identify risks and devise coping strategies to reduce the probability of occurrence of risk agents by providing risk agents with precautions. (Abryandoko \& Mushthofa, 2020).

\section{The House of Risk (HOR) Method}

The sequence uses the HOR method where HOR is divided into 2 models, namely HOR 1 and HOR 2 as follows (Wahyudin et al., 2016); (1) Identifying farmer activities using the SCOR model which includes several processes, namely plan, source, make, delivery and return; (2) Identify risk events where the risk describes all events that are likely to arise and result in losses to farmers; (\#) Identify the measurement of the level of impact ( $\mathrm{Si}$ ) where the resulting value knows how much disturbance caused by (Ei). to find ( $\mathrm{Si})$ as follows:

$$
S_{i}=\sqrt[k]{S_{i 1} x S_{i 2} x \ldots x S_{i k}}
$$

Information

$S i=$ Level of impact of a risk (sererity level of risk)

$\mathrm{i}=1,2,3, \ldots . \mathrm{n}$

$\mathrm{k}=$ people's assessment to $-\mathrm{k}$

(4) Identifying the risk causative agent which aims to find out what factors can cause a risk event to occur; (5) Measuring the occurrence value or the opportunity value of the emergence of a risk agent. To find the occurrence level risk as follows:

$$
O_{j}=\sqrt[k]{O_{j 1} x O_{j 2} x \ldots x O_{j k}}
$$

Description

$\mathrm{Oj}=$ The occurrence level of risk

$\mathrm{j}=1,2,3, \ldots . . \mathrm{m}$

$\mathrm{k}=$ rating of the $\mathrm{k}$-th person

(6) Look for the correlation value between risk events and risk-causing agents where the resulting correlation value consists of $0.1,3,9$ where 0 indicates no correlation relationship, 1 describes a small correlation relationship, 3 describes a moderate correlation and 9 describes a high correlation; (7) Calculation of the ARP value that will be used as consideration for determining the priority of risk management which will be input in HOR 2 later. The following is the calculation of the ARP value:

$$
A R P_{j}=O_{j} \sum S_{i} R_{i j}
$$

Description

$\mathrm{ARPj}=$ Aggregate Risk Potential (risk priority index)

$\mathrm{Oj}=$ The occurrence level of risk

$\mathrm{Si}=$ the level of impact of a risk (severity level of risk)

$\mathrm{Rij}=$ Correlation between risk and risk genes

Description 
$\mathrm{ARPj}=$ Aggregate Risk Potential (risk priority index)

$\mathrm{Oj}=$ Risk occurrence rate (occurance $1 \bullet$ Output HOR 1 which will be used as input in HOR 2.

(8) For HOR 2, the initial stage begins by selecting risk agents from the highest to the lowest ARP values using Pareto analysis; (9) If the risk agent is included in the priority category, the next step is to identify the relevant mitigation actions (PAk) for the risk agent. If the risk agent is not a priority agent then the agent is not processed further and is completed; (10) Measuring the correlation value of the agent with risk management where the correlation value is; (11) Calculates (TEk) with the following formula:

level of risk)

$\mathrm{Si}=$ the level of impact of a risk (severity level of risk)

$\mathrm{Rij}=$ Correlation between risk and risk genes

$$
T E_{k}=\sum A R P_{j} E_{j k}
$$

Description

TEk $=$ Total effectiveness

$\mathrm{ARPj}=$ risk priority (risk priority index)

Ejk $=$ Correlation value between a risk agent and risk management

(12) Measuring the level of difficulty in implementing mitigation actions ( $\mathrm{Dk}$ ) to reduce the emergence of risk agents; (13) Calculate the total (ETDk) with the following formula:

$$
E T D_{k}=\frac{T E_{k}}{D_{k}}
$$

Description

ETDk $=$ effectiveness to difficulty of ratio

TEk $=$ Total effectiveness

Dk = Difficulty level to take preventive measures to be implemented in the company.

(14) Measuring the priority scale where the main priority value is given to the mitigation action that has the highest ETD value; (15) Phase 2 HOR outputs.

\section{Results and Discussion}

\section{Farmer}

Research Results from the results of research carried out by field research methods, namely research conducted directly with the object of research. The determination of the research area was carried out purposively, namely in the District of Rammang-Rammang. The sampling in this study was 10 people from the Farmers of the Rammang-Rammang District of Buli-Buli farmer groups including 5 salin minapadi farmers and 5 non-minapadi farmers.

\section{Salin Minapadi Farmers in Rammang-rammang}

Salin Minapadi farmers are farmers who carry out Minapadi activities in brackish water located in Rammang-Rammang District, Maros Regency. Salin Minapadi cultivation is an integration of tiger shrimp cultivation technology with salin-tolerant rice varieties by utilizing idle land caused by seawater intrusion. So that farmers are very enthusiastic about the salin mining 
activity because so far the farmers' land has been unemployed due to seawater intrusion which has resulted in crop failure so that now farmers can switch to salin minapadi farmers.

\section{Non Minapadi Farmers in Rammang-rammang}

In the District of Rammang-Rammang, not all farmers understand the information on copying minapadi. There are still many farmers who think that even salin minapadi cultivation requires more capital and more complicated maintenance. So that there are still many farmers who continue to carry out farming activities to plant rice only and do not carry out salin mining activities. For this reason, non-Minapadi farmers do not carry out their Minapadi activities. Samples of non-minapadi salin are still needed for comparison, taken as many as 5 non-salin farmers.

\section{Minapadi Copy}

\section{Minapadi Production Costs Copy}

Production costs for salin minapadi farmers include the use of seeds, the use of tiger shrimp fry, the use of fertilizers, the use of biopesticides, fuel and equipment depreciation costs. For details of production costs incurred by salin minapadi farmers in Rammang-rammang District, Maros Regency, it can be seen in the following table:

Table 1. Minapadi Production Costs Copy

\begin{tabular}{|c|c|c|}
\hline No. & Details & Average/Ha/MT (Rp) \\
\hline 1 & Seed Cost & 200.000 \\
\hline 2 & Fertilizer Cost & 350.000 \\
\hline 3 & Cost of Pesticides & 325.000 \\
\hline 4 & Cost of Benur Shrimp Windu & 600.000 \\
\hline 5 & Fuel Costs & 78.500 \\
\hline 6 & Tool Depreciation Expense & 120.333 \\
\hline \multicolumn{2}{|c|}{ TOTAL } & 1.673 .833 \\
\hline
\end{tabular}

From table 1 it can be seen that the total production cost of minapadi copy is Rp. 1,673,833 incurred during the salin minapadi farming process in Rammang-rammang District, where the variable costs of land rent are not calculated because the land is privately owned and labor costs are not calculated because it is done by the farmers themselves.

\section{Minapadi Farmers Acceptance}

Salary minapadi farmers' income is the income received during the growing season (TM) and in 1 growing season it takes 120 days or 4 months in the farming process, the length of the enlargement process for tiger prawns is the cause of the length of the salin minapadi farming process.

Table 2. Acceptance of Minapadi Farmers Copy

\begin{tabular}{|c|c|c|c|}
\hline Information & Results (kg) & Selling Price & Total \\
\hline Grain & 5000 & $\operatorname{Rp~4,000~}$ & $\operatorname{Rp~20,000,000~}$ \\
\hline Shrimp windu & 280 & $\operatorname{Rp~70,000}$ & $\operatorname{Rp~19.600.000~}$ \\
\hline \multicolumn{3}{|c|}{ TOTAL } & $\operatorname{Rp~39.600.000~}$ \\
\hline
\end{tabular}

From the results of the calculations in Table 2, it can be seen that the revenue from salin minapadi farming from the production of salin minapadi farmers produced $280 \mathrm{~kg}$ of tiger prawns and $5000 \mathrm{~kg}$ of grain with a total income of minapadi farmers of $\mathrm{Rp}$. $39,600,000 / \mathrm{ha} / \mathrm{MT}$. 


\section{Minapadi Farmers Profits}

Salin minapadi farmers' profits are generated from total revenue minus production costs (Kurnia Ilahi et al., 2019). Salin Minapadi farmers benefit greatly from selling tiger prawns.

Table 3. Profits for salin minapadi farmers

\begin{tabular}{|c|c|c|c|c|}
\hline Sample & Land area (Ha) & Acceptance & Total Cost & Advantage \\
\hline 1 & 1 & $\operatorname{Rp} 39.600 .000$ & $\operatorname{Rp~1,673,833}$ & $\operatorname{Rp~37,926,167~}$ \\
\hline 2 & 0,4 & $\operatorname{Rp~} 15.280 .000$ & $\operatorname{Rp~743,600}$ & $\operatorname{Rp~14,536,400~}$ \\
\hline 3 & 0,5 & $\operatorname{Rp} 18.400 .000$ & $\operatorname{Rp~942.917}$ & $\operatorname{Rp~17,457,083~}$ \\
\hline 4 & 0,7 & $\operatorname{Rp} 27.720 .000$ & $\operatorname{Rp~1,213,050~}$ & $\operatorname{Rp~26,506,950}$ \\
\hline 5 & 0,2 & $\operatorname{Rp~7,920,000}$ & $\operatorname{Rp~383,967}$ & $\operatorname{Rp~7,536,033}$ \\
\hline
\end{tabular}

From table 3, it can be seen that the profit for salin minapadi farmers reaches Rp. $37,926,167 / \mathrm{Ha} / \mathrm{MT}$.

\section{Risk Identification}

\section{House of Risk Analysis}

Table 4. Identification of SCOR Business Process Model

\begin{tabular}{|c|c|c|c|}
\hline No. & Process & Activity & Code \\
\hline \multirow{2}{*}{1} & \multirow{2}{*}{ Plan (Planning) } & $\begin{array}{l}\text { Planning errors in the cultivation of salin minapadi } \\
\text { result in risks to production planning activities. }\end{array}$ & E1 \\
\hline & & $\begin{array}{l}\text { Weather prediction errors result in risks to planning } \\
\text { activities }\end{array}$ & E2 \\
\hline \multirow[t]{2}{*}{2} & \multirow{2}{*}{$\begin{array}{c}\text { Source } \\
\text { (Procurement) }\end{array}$} & $\begin{array}{c}\text { Difficulty in finding a workforce that understands in } \\
\text { the cultivation of salin minapadi resulting in risks to } \\
\text { the cultivation activities of copy minapadi }\end{array}$ & E3 \\
\hline & & $\begin{array}{l}\text { Difficulty procuring materials such as shrimp windu } \\
\text { resulting in risks to the activities of copy minapadi }\end{array}$ & E4 \\
\hline \multirow{4}{*}{3} & \multirow{4}{*}{$\begin{array}{l}\text { Make } \\
\text { (Production } \\
\text { process) }\end{array}$} & $\begin{array}{l}\text { Errors in managing the cultivation of salin minapadi } \\
\text { result in risks to the cultivation activities of copy } \\
\text { minapadi. }\end{array}$ & E5 \\
\hline & & $\begin{array}{l}\text { Errors in handling plant disrupting organisms (OPT) } \\
\text { result in risks to the cultivation of salin minapadi }\end{array}$ & E6 \\
\hline & & $\begin{array}{l}\text { Technical errors in the cultivation of salin minapadi } \\
\text { result in risks in the cultivation of salin minapadi }\end{array}$ & E7 \\
\hline & & $\begin{array}{c}\text { Misinformation in the cultivation of salin minapadi } \\
\text { resulting in risk }\end{array}$ & E8 \\
\hline 4 & $\begin{array}{c}\text { Deliver } \\
\text { (delivery) }\end{array}$ & $\begin{array}{l}\text { Improper budget planning results in risks to the } \\
\text { cultivation of copy minapadi }\end{array}$ & E9 \\
\hline 5 & $\begin{array}{l}\text { Return } \\
\text { (Return) }\end{array}$ & $\begin{array}{l}\text { The quality of the resulting product is not of quality } \\
\text { resulting in a decreased sales risk }\end{array}$ & E10 \\
\hline
\end{tabular}

From the results of data observations, it is found that the data recapitulation of the priority risk Severity assessment through the HOR method, the risk assessment data can be seen in Table 5. 
Table 5. Risk Assessment

\begin{tabular}{|c|c|c|}
\hline Code & Risk & Severity \\
\hline E1 & $\begin{array}{c}\text { Planning errors in the cultivation of salin minapadi result in } \\
\text { risks to production planning activities. }\end{array}$ & 4 \\
\hline E2 & Weather prediction errors result in risks to planning activities & 8 \\
\hline E3 & $\begin{array}{c}\text { Difficulty in finding a workforce that understands in the } \\
\text { cultivation of salin minapadi resulting in risks to the } \\
\text { cultivation activities of copy minapadi }\end{array}$ & 3 \\
\hline E4 & $\begin{array}{c}\text { Difficulty procuring materials such as resulting in risks to } \\
\text { copy minapadi activities }\end{array}$ & 6 \\
\hline E5 & $\begin{array}{c}\text { Errors in managing the cultivation of salin minapadi result in } \\
\text { risks to the cultivation activities of copy minapadi. }\end{array}$ & 4 \\
\hline E6 & $\begin{array}{c}\text { Errors in handling plant disrupting organisms (OPT) result in } \\
\text { risks to the cultivation of salin minapadi }\end{array}$ & 3 \\
\hline E7 & $\begin{array}{c}\text { Technical errors in the cultivation of salin minapadi result in } \\
\text { risks in the cultivation of salin minapadi }\end{array}$ & 4 \\
\hline E8 & $\begin{array}{c}\text { Misinformation in the cultivation of salin minapadi resulting } \\
\text { in risk }\end{array}$ & 8 \\
\hline E9 & $\begin{array}{c}\text { Improper budget planning results in risks to the cultivation of } \\
\text { copy minapadi }\end{array}$ & 2 \\
\hline E10 & $\begin{array}{c}\text { The quality of the resulting product is not of quality resulting } \\
\text { in a decreased sales risk }\end{array}$ & 4 \\
\hline
\end{tabular}

Based on the risk assessment that has been carried out, the severity value or level of impact of the risk is 1 risk with a severity value of 2, 2 risks have a severity value of 3, 4 risks have a severity value of 4,1 risk has a severity value of 6 , and 2 risks has a severity value of 8 .

From the results of data observations and risk assessments, it is also obtained a recapitulation of risk assessment Occurance data through the HOR method, the risk assessment data can be seen in Table 6.

Table 6. Occurance Value

\begin{tabular}{|c|c|c|}
\hline Code & Causes of Risk & Occurance \\
\hline A-1 & Difficulty finding materials & 4 \\
\hline A-2 & Floods and Long Droughts & 8 \\
\hline A-3 & Lack of manpower in agriculture & 2 \\
\hline A-4 & Shrimp windu has increased in price & 5 \\
\hline A-5 & Too dry land causes too high salinity & 2 \\
\hline A-6 & Late delivery of biopesticides & 2 \\
\hline A-7 & Misunderstanding in the cultivation of salin minapadi & 6 \\
\hline A-8 & Lack of communication with institutions & 5 \\
\hline A-9 & Sudden request & 8 \\
\hline A-10 & Contamination occurs & 5 \\
\hline
\end{tabular}

For risk causes, 3 risk causes have an occurrence value of 2, 1 risk cause has an occurrence value of 4, 3 risk causes have an occurrence value of 5, 1 risk cause has an occurrence value of 6 and 2 risk causes have an occurrence value of 8 . 


\section{House of Risk Phase 1}

After obtaining the occurrence and severity values of each risk event and risk agent, the next step is the preparation of the House of Risk Phase 1 with the following steps (Andriyanto \& Mustamin, 2020) :

\section{Determine the correlation between risk events and risk agents}

The value of the correlation ranking is (0) meaning there is no relationship, (1) meaning a weak relationship, (3) meaning a moderate relationship, (9) meaning a strong relationship. After assessing the correlation of the relationship, then calculating the value of Aggregate Risk Potentials (ARP) with the formula $\boldsymbol{A R P} \boldsymbol{P}_{\boldsymbol{j}}=\boldsymbol{O}_{\boldsymbol{j}} \sum \boldsymbol{S}_{\boldsymbol{i}} \boldsymbol{R}_{\boldsymbol{i} \boldsymbol{j}}$. The results of the calculation can be seen in Table 7.

Table 7. Aggregate Risk Potentials (ARP) Scheme

\begin{tabular}{|c|c|c|c|c|c|c|c|c|c|c|c|}
\hline \multirow{2}{*}{ Risk event } & \multicolumn{10}{|c|}{ Risk Agent } & \multirow{2}{*}{$\begin{array}{l}\text { Severity of } \\
\text { risk }\end{array}$} \\
\hline & A1 & A2 & A3 & A4 & A5 & A6 & A7 & A8 & A9 & A10 & \\
\hline E1 & 9 & & & 9 & 3 & & 1 & 1 & 3 & & 4 \\
\hline E2 & & 9 & 9 & 3 & 9 & & & & 1 & 1 & 8 \\
\hline E3 & 1 & & 9 & & & & & & & & 3 \\
\hline E4 & 9 & 3 & 1 & & & 9 & & 3 & 9 & & 6 \\
\hline E5 & & & 1 & & 9 & 9 & 9 & 9 & & & 4 \\
\hline E6 & & & & & & 3 & 9 & 9 & & & 3 \\
\hline E7 & & 3 & & & 9 & 3 & 9 & 9 & & & 4 \\
\hline E8 & & & & & 1 & & 9 & 9 & & & 8 \\
\hline E9 & & & & 9 & & & & & 9 & & 2 \\
\hline E10 & & & & & 1 & 1 & & & & 9 & 4 \\
\hline $\begin{array}{c}\text { Occurrence of } \\
\text { Agent }\end{array}$ & 4 & 8 & 2 & 5 & 2 & 2 & 6 & 5 & 8 & 5 & \\
\hline ARP & 372 & 816 & 218 & 390 & 336 & 230 & 1050 & 965 & 736 & 220 & \\
\hline Ranking & 6 & 3 & 10 & 5 & 7 & 8 & 1 & 2 & 4 & 9 & \\
\hline
\end{tabular}

Next sort according to the largest ARP value as in Table 8 as follows:

Table 8. Risk Agent Priority Order Scheme

\begin{tabular}{|c|c|c|}
\hline Code & Rank & ARP \\
\hline A7 & 1 & 1050 \\
\hline A8 & 2 & 965 \\
\hline A2 & 3 & 816 \\
\hline A9 & 4 & 736 \\
\hline A4 & 5 & 390 \\
\hline A1 & 6 & 372 \\
\hline A5 & 7 & 336 \\
\hline A6 & 8 & 230 \\
\hline A10 & 9 & 220 \\
\hline A3 & 10 & 218 \\
\hline
\end{tabular}




\section{Create a risk map}

After knowing the dominant source of risk, then do a mapping of the causes of risk. This risk mapping uses a range based on the ARP value that shows the level of risk cause in accordance with the ARP value obtained as in Table 9 as follows.

Table 9. Scheme of Salin Minapadi Cultivation Risk Map

\begin{tabular}{|c|c|c|}
\hline Rank & Causes of Risk & ARP \\
\hline 1 & Misunderstanding in the cultivation of salin minapadi & 1050 \\
\hline 2 & Lack of communication with institutions & 965 \\
\hline 3 & Floods and long droughts & 816 \\
\hline 4 & Sudden request & 736 \\
\hline 5 & Shrimp windu has increased in price & 390 \\
\hline 6 & Difficulty finding materials & 372 \\
\hline 7 & Too dry land causes too high salinity & 336 \\
\hline 8 & Late administration of pesticides & 230 \\
\hline 9 & Contamination occurs & 220 \\
\hline 10 & Lack of labor in farming & 218 \\
\hline
\end{tabular}

\section{House of Risk Phase 2}

The next step is the preparation of House of Risk Phase II, namely with the following steps: (Ridwan et al., 2019) :

\section{Determine precautions}

After creating a risk map the next step is to determine preventive action for the mitigation process. Risk mitigation strategies can be seen in Table 10.

Table 10. Mitigation strategies

\begin{tabular}{|c|c|}
\hline Mitigation Action & $\begin{array}{c}\text { Mitigation Code } \\
\text { (PA) }\end{array}$ \\
\hline Improve communication both internally and externally & PA1 \\
\hline $\begin{array}{c}\text { Institutional consistently provide farmers with } \\
\text { information related to salin minapadi }\end{array}$ & PA2 \\
\hline Using the right type of rice verietas & PA3 \\
\hline Maintaining water salinity in rice fields & PA4 \\
\hline OPT control as agreed with procedure & PA5 \\
\hline Manage copy minapadi appropriately & PA6 \\
\hline
\end{tabular}

Measure the correlation value of risk agents with mitigation actions (preventive measures). Can be seen in Table 11.

Table 11. values of correlation of agent risk with mitigation action

\begin{tabular}{|c|c|c|c|c|c|c|c|}
\hline & PA1 & PA2 & PA3 & PA4 & PA5 & PA6 & ARP \\
\hline A7 & 9 & 9 & 9 & & 3 & & 1050 \\
\hline A8 & 9 & 9 & 3 & & & & 965 \\
\hline $\mathrm{A} 2$ & & & & 9 & & 9 & 816 \\
\hline A9 & 1 & & & & & & 736 \\
\hline A4 & & & & & & & 390 \\
\hline A1 & & & 9 & & & & 372 \\
\hline A5 & & & & 9 & & 9 & 336 \\
\hline
\end{tabular}

Copyright $\odot$ 2022, Journal of Asian Multicultural Research for Economy and Management Study, 


\begin{tabular}{|c|c|c|c|c|c|}
\hline A6 & 1 & & 9 & 9 & 230 \\
\hline A10 & & 1 & 1 & 9 & 220 \\
\hline A3 & & & & & 218 \\
\hline
\end{tabular}

\section{Search for the total value of the activity}

Calculate or search for the total value of activity. The results of the calculation can be seen in Table 12

Table 12. Total activity value

\begin{tabular}{|c|c|c|}
\hline Code & Description of risk management & $\begin{array}{c}\text { Total effectiveness } \\
\text { (TEk) }\end{array}$ \\
\hline PA1 & $\begin{array}{c}\text { Improve communication both internally and } \\
\text { externally }\end{array}$ & 18.871 \\
\hline PA2 & $\begin{array}{c}\text { Institutional consistently provide farmers with } \\
\text { information related to salin minapadi }\end{array}$ & 18.365 \\
\hline PA3 & Using the right type of rice verietas & 15.693 \\
\hline PA4 & Maintaining water salinity in rice fields & 10.588 \\
\hline PA5 & OPT control as agreed with procedure & 5.440 \\
\hline PA6 & Manage copy minapadi appropriately & 14.418 \\
\hline
\end{tabular}

\section{Measure the level of difficulty}

Estimate the level of difficulty in performing each action. Weight 3 for mitigation action is easy to implement. Weight 4 for mitigation action that is rather difficult to implement and weight 5 for mitigation action that salit applied. Can be seen in Table 13.

Table 13. Measures difficulty levels

\begin{tabular}{|c|c|c|}
\hline Code & Mitigation action & Difficulty level \\
\hline PA1 & $\begin{array}{c}\text { Improve communication both internally and } \\
\text { externally }\end{array}$ & 3 \\
\hline PA2 & $\begin{array}{c}\text { Institutional consistently provide farmers with } \\
\text { information related to salin minapadi }\end{array}$ & 4 \\
\hline PA3 & Using the right type of rice verietas & 5 \\
\hline PA4 & Maintaining water salinity in rice fields & 4 \\
\hline PA5 & OPT control as agreed with procedure & 3 \\
\hline PA6 & Manage copy minapadi appropriately & 3 \\
\hline
\end{tabular}

\section{Calculate total effectiveness}

Calculating total effectiveness can be seen in Table 14 .

Table 14. Calculates total effectiveness

\begin{tabular}{|c|c|c|c|c|c|c|}
\hline & PA1 & PA2 & PA3 & PA4 & PA5 & PA6 \\
\hline A7 & 9 & 9 & 9 & & 3 & \\
\hline A8 & 9 & 9 & 3 & & & \\
\hline A2 & & & & 9 & & 9 \\
\hline A9 & 1 & & & & & \\
\hline A4 & & & & & & \\
\hline A1 & & & 9 & & & \\
\hline A5 & & & & 9 & & 9 \\
\hline A6 & & 1 & & & 9 & 9 \\
\hline
\end{tabular}

Copyright (C 2022, Journal of Asian Multicultural Research for Economy and Management Study, 


\begin{tabular}{|c|c|c|c|c|c|c|}
\hline $\mathrm{A} 10$ & & & & 1 & 1 & 9 \\
\hline $\mathrm{A} 3$ & & & & & & \\
\hline $\mathrm{TeK}$ & 18871 & 18365 & 15693 & 10588 & 5440 & 14418 \\
\hline $\mathrm{Dk}$ & 3 & 3 & 4 & 5 & 4 & 3 \\
\hline ETD & 6290,333 & 6121,667 & 3923,25 & 2117,6 & 1360 & 4806 \\
\hline ranking & 1 & 2 & 3 & 5 & 6 & \\
\hline
\end{tabular}

\section{Minapadi Advantages}

From the results of the analysis of the benefits of minapadi salin cultivation in Rammangrammang District, Maros Regency, Table 2 shows that the profit obtained in salin minapadi cultivation is Rp. $37.926 .167 / \mathrm{Ha} / \mathrm{MT}$. The value of the profit is obtained from the reduction of income with total costs (D. T. Lestari et al., 2019). This shows that salin mining activities will increase the yield of farmers' profits where farmers get results from the sale of grain and tiger prawns.

Some of the benefits obtained from the Salin Minapadi business in Rammang-Rammang are; (1) Increase the profits of farmers who experience crop failure due to increased pest attacks due to climate change, with the presence of tiger prawns in the fields it will help consume pests; (2) Saving expenditure on the use of subsidized fertilizers where farmers reduce $50 \%$ of their use of fertilizers; (3) Obtaining two results at once, namely grain and tiger prawns; (5) In the management of salin oil and gas, it saves energy and fuel costs because it is only one time plowing

Minapadi advantages from the economic aspect, among others, Minapadi is the right choice for diversification, because Minapadi is the most efficient system in reducing costs, especially for the use of fertilizers, pesticides and farmer's labor in plowing the fields (Widhiningsih \& Kriska, 2021).

\section{Identify Risk using House of Risk 1}

House of Risk phase 1 is the initial stage for the House Of Risk method, where HOR phase 1 is a risk identification phase that is used to determine risk agents that must be given priority for preventive action (Samodro, 2020). In Table 3 it is known that there are 10 activities of salin minapadi farmers which are risk factors in salin minapadi cultivation, namely; (1) Errors in planning for salin minapadi cultivation result in risks to production planning activities; (2) Mistakes in weather predictions result in risks to planning activities; (3) Difficulties in finding workers who understand salin minapadi cultivation pose a risk to salin minapadi cultivation activities; (4) Difficulties in procuring materials such as tiger prawns pose a risk to salin mining activities; (5) Errors in managing salin minapadi cultivation result in risks to salin minapadi cultivation activities; (6) Errors in handling plant pest organisms (OPT) result in risks to salin minapadi cultivation activities; (7) Technical errors in salin minapadi cultivation result in risks in salin minapadi cultivation; (8) Misinformation in salin minapadi cultivation results in risks; (9) Improper budget planning results in risks to the results of salin minapadi cultivation; (10) The quality of the resulting product is not of high quality resulting in decreased sales risk

Those who get the severity value or the level of impact from the greatest risk are weather prediction errors and misinformation in salin minapadi cultivation. The causes of risk factors are as follows; (1) Difficulty finding materials; (2) Floods and long droughts; (3) Lack of manpower in farming; (4) Tiger prawns have increased in price; (5) Land is too dry resulting in too high salinity; (6) Late administration of biopesticides; (7) Misunderstanding in salin minapadi cultivation; (8) Lack of communication with institutions; (9) A sudden request; (!0) The occurrence of contamination. 
After conducting the HOR 1 analysis, those who get the highest risk causes are misunderstandings in salin minapadi cultivation, lack of communication with institutions and the occurrence of floods and droughts. So in salin Minapadi cultivation it is necessary to communicate with institutions that know more about the system in salin Minapadi cultivation. Through a communication approach, it is hoped that it can provide understanding to farmers in improving the quality of salin Minapadi cultivation (Mulyadi et al., 2020).

\section{Risk Management by using the House of Risk 2}

The second stage in the House Of Risk method is HOR phase 2. In HOR phase 2, several treatment strategies will be selected which are considered effective to reduce the probability of impacts caused by risk agents (Rozudin \& Mahbubah, 2021). This step in HOR phase 2 begins with designing a treatment strategy, how to manage risk well, looking for a large relationship between the handling strategy and existing risk agents (Zul Mazwan et al., 2020).

There are 6 appropriate risk management proposals that are considered suitable for salin Minapadi farmers in salin Minapadi cultivation, namely; (1) Improve communication both internally and externally; (2) Institutions consistently provide farmers with information related to salin oil and gas; (3) Using the right types of rice varieties; (4) Maintain water salinity in rice fields; (5) Control of pests according to procedures; (6) Precisely manage the minapadi copy

The results obtained are risk management that really needs to be done by salin minapadi farmers is to improve communication both internally and externally with a weight value of 3 which means it is easy for salin minapadi farmers to do. With this management strategy, it is hoped that the impact of crop failure on Minapadi cultivation can be minimized by farmers (Ahmadian \& Yustiati, 2021).

\section{Conclusion}

From the results and discussions carried out in the field, it can be concluded that; (1) The average profit of salin minapadi farmers while cultivating salin minapadi in Rammangrammang District, Maros Regency in one growing season is IDR 37,928,167/ha/MT. Minapadi salin is very feasible to be carried out by farmers who have land in brackish water areas due to seawater intrusion where farmers are able to use idle land by reusing the land and are able to generate very large profits; (2) Based on the results of the analysis of the risk factors that are most often experienced by salin minapadi farmers, Rammang-rammang District, Maros Regency and there is a possibility of failure in salin minapadi cultivation results from the priority risk agent using the House of Risk 1 model, the 10 largest orders are obtained as risk agent priorities based on the Aggregate Risk value. Potential (ARP) are (A7) Misunderstanding in salin minapadi cultivation, (A8) lack of communication with institutions, (A2) Floods and long droughts, (A9) sudden demand, (A4) tiger prawns experiencing price increases, ( A1) difficulty in finding materials, (A5) the land is too dry so the salinity is high, (A6) the pesticide application is late, (A10) contamination occurs, (A3) lack of labor in farming; (3) The prevention of risk factors that occur to manage risks that occur in the failure of salin Minapadi cultivation obtain 6 priorities in handling salin Minapadi cultivation in preventing harvest failures, namely improving communication both internally and externally, institutions consistently providing farmers with information related to salin Minapadi, using types of rice varieties. proper management, maintaining water salinity in paddy fields, controlling pests according to procedures, and managing salin mines appropriately. 


\section{Suggestion}

It is hoped that the government will be able to introduce salin Minapadi cultivation to farmers who have land that is unemployed due to seawater intrusion and invite farmers to implement salin Minapadi cultivation in order to increase farmers' profits. It is hoped that the government will be able to introduce new rice varieties that are resistant to brackish water up to $10 \mathrm{ppt}$, namely Inpari 34 Salin Agritan. For further researchers, it is hoped that they will be able to analyze the effect of the strategy that has been obtained.

\section{References}

Abryandoko, E. W., \& Mushthofa, M. (2020). Strategi Mitigasi Resiko Supply Chain Dengan Metode House of Risk. Rekayasa Sipil, 14(1), 26-34.

Ahmadian, I., \& Yustiati, A. (2021). Produktivitas Budidaya Sistem Mina Padi Untuk Meningkatkan Ketahanan Pangan Di Indonesia: A Review Abstrak Mina Padi Cultivation Productivity To Improve Food Security In Indonesia: A Review Pendahuluan Pangan merupakan komoditas strategis dan selalu men. Jurnal Akuatek, 2(1), 1-6.

Andriyanto, A., \& Mustamin, N. K. (2020). Analisis Manajemen Risiko Dan Strategi Penanganan Risiko Pada PT Agility International Menggunakan Metode House Of Risk (Hor). Jurnal Logistik Bisnis, 10(02), 4-11.

Badriyah, N., Tauhid, H., \& Rasmawati DJ, Y. (2020). Pendampingan Penerapan Sistem Minapadi Dalam Upaya Peningkatan Pendapatan Kelompok Tani Di Desa Guci Kabupaten Lamongan. Jurnal Karya Abdi Masyarakat, 4(2), 221-227. https://doi.org/10.22437/jkam.v4i2.10524

Fatimah, I. N., Iskandar, J., \& Partasasmita, R. (2020). Ethnoecology of paddy-fish integrative farming (Minapadi) in lampegan village, west java, indonesia. Biodiversitas, 21(9), 4419-4432. https://doi.org/10.13057/biodiv/d210961

Hadi, J. A., Febrianti, M. A., Yudhistira, G. A., \& Qurtubi, Q. (2020). Identifikasi Risiko Rantai Pasok dengan Metode House of Risk (HOR). Performa: Media Ilmiah Teknik Industri, 19(2), 85-94.

Kurnia Ilahi, M., Wahyuni, S., \& Usman, Y. (2019). Analisis Perbandingan Pendapatan dan Keuntungan Usaha Tani Minapadi dengan Padi Konvensional di Nagari Talang Maur Kecamatan Mungka Kabupaten Lima Puluh Kota. JOSETA: Journal of SocioEconomics on Tropical Agriculture, 1(1), 18-27.

Lestari, D. T., Sumarjono, D., \& Ekowati, T. (2019). Analisis Pendapatan Usahatani Minapadi Di Kabupaten Sukoharjo. SOCA: Jurnal Sosial, Ekonomi Pertanian, 13(3), 304. https://doi.org/10.24843/soca.2019.v13.i03.p02

Lestari, S., \& Bambang, A. N. (2017). Penerapan Minapadi dalam Rangka Mendukung Ketahanan Pangan dan Meningkatkan Kesejahteraan Masyarakat. Proceeding Biology Education Conference, 14(1), 70-74.

Mulyadi, H., Rochdiani, D., \& Hakim, D. L. (2020). Analisis Usahatani Minapadi (Studi Kasus pada Kelompok Tani Fajar Jayamukti di Desa Jayamukti Kecamatan Leuwisari Kabupaten Tasikmalaya). Jurnal Ilmiah Mahasiswa Agroinfo Galuh, 7(1), 45.

Prasetyo, M. N., Hartono, S., \& Masyhuri, M. (2018). The Analysis Of Business, Risk, And Development Strategy Of Minapadi (Paddy-Fish Integration Farming System) In Sleman District. Agro Ekonomi, 29(1), 64. 
Ridwan, A., Trenggonowati, D. L., \& Parida, V. (2019). Usulan Aksi Mitigasi Risiko Rantai Pasok Halal Pada Ikm Tahu Bandung Sutra Menggunakan Metode House of Risk. Journal Industrial Servicess, 5(1), 112-120.

Rozudin, M., \& Mahbubah, N. A. (2021). Implementasi Metode House Of Risk Pada Pengelolaan Risiko Rantai Pasokan Hijau Produk Bogie S2hd9c (Studi Kasus: PT Barata Indonesia). JISI: Jurnal Integrasi Sistem Industri, 8(1), 1-11.

Samodro, G. (2020). Pendekatan House Of Risk Untuk Penilaian Risiko Alur Penyediaan Dan Pendistribusian Obat (Studi Kasus Pada Apotek ABC). Opsi, 13(2), 92.

Sauqie, M., Elfitasari, T., \& Rejeki, S. (2017). Analisa Usaha Kegiatan Budidaya Minapadipada Kelompok Mina Makmur dan Kelompok Mina Murakabi di Kabupaten Sleman. Journal of Aquaculture Management and Technology, 6(1), 1-7.

Wahyudin, N. E., \& Santoso, I. (2016). Modelling of Risk Management for Product Development of Yogurt Drink Using House of Risk (HOR) Method. The Asian Journal of Technology Management (AJTM), 9(2), 98-108.

Widhiningsih, D. F., \& Kriska, M. (2021). Model Inovasi Minapadi dan Peran Aktor yang Mendukung Diseminasi Inovasi Minapadi di Kabupaten Sleman. Interdisciplinary Journal on Law, Social Sciences and Humanities, 02(1), 67-77.

Winarso, K., \& Jufriyanto, M. (2020). Rework Reduction and Quality Cost Analysis of Furniture Production Processes Using the House of Risk (HOR). Journal of Physics: Conference Series, 1569(3).

Zul Mazwan, M., Tarik Ibrahim, J., \& A M Fadlan, W. (2020). Risk Analysis of Shallot Farming in Malang Regency, Indonesia. Agricultural Social Economic Journal, 20(3), 201-206 